\title{
KSZTALTOWANIE REGIONALNEJ I LOKALNEJ SIECI OSADNICZEJ W POLSCE W ŚWIETLE IDEI ZRÓWNOWAŻONEGO ROZWOJU
}

\section{WPROWADZENIE}

Wraz z przyjęciem Konstytucji Rzeczypospolitej Polskiej w 1997 r. zrównoważony rozwój stał się podstawową zasada, która przyświecać powinna wszystkim działaniom, podejmowanym na różnych szczeblach organizacji terytorialnej kraju. Na każdym z tych szczebli rozwój taki wiąże się z realizacją różnych celów. Inne zatem będą cele zrównoważonego rozwoju w skali regionalnej, a inne w lokalnej, jakkolwiek pewne cele mogą być wspólne. Skala lokalna wiązana jest przede wszystkim z lokalnym środowiskiem życia ludności i zaspokojeniem podstawowych potrzeb społecznych, skala regionalna natomiast w większym stopniu z podtrzymywalnością rozwoju, rozumiana jako gospodarowanie w ramach ograniczeń stawianych przez środowisko przyrodnicze, przy wykorzystaniu regionalnych uwarunkowań rozwoju, a zatem w większym stopniu z aspektami gospodarczymi. Ze względu na to, że zrównoważony rozwój, oprócz aspektu społecznego, gospodarczego i przyrodniczego, ma także aspekt przestrzenny, istotną rolę w osiąganiu celów takiego rozwoju odgrywać będzie sposób rozmieszczenia ludności, majacy swoje odzwierciedlenie w strukturze sieci osadniczej obszaru ${ }^{1}$. Kwestia pozostaje to, jaka struktura osadnicza, bardziej monocentryczna czy policentryczna, pozwoli lepiej osiagać cele zrównoważonego rozwoju regionalnego i lokalnego, a także to, jak taką pożądaną strukturę przestrzenną kształtować. Wydaje się, że istotna rolę w tym względzie odgrywać powinny różnego typu, uchwalane przez władze samorządowe akty planistyczne, w szczególności te z zakresu planowania przestrzennego, z których zapisów wynikać powinno, jaka sieć osadnicza w danej skali przestrzennej będzie najefektywniejsza i jakie działania należy podejmować, aby taką sieć ukształtować. Na rozwój sieci osadniczej na danym szczeblu organizacji terytorialnej wpływać będą oczywiście w znacznym stopniu także zapisy zawarte w dokumentach wyższego rzędu. Oznacza to, że na rozmieszczenie ludności w skali regionalnej wpływać będa, oprócz regionalnej polityki rozwoju, także regulacje, polityka i działania podejmowane na szczeblu krajowym, oddziałujące następnie w określony sposób na skalę lokalną (Koncepcja Przestrzennego Zagospodarowania Kraju, tzw. KPZK). Oczywiste

${ }^{1}$ V. H. Dale, R. A. Efroymson, K. I. Kline, The land use-climate change-energy nexus, „Landscape Ecology" 26, 2011, s. 755-773. 
jest, że w warunkach demokracji i gospodarki wolnorynkowej decyzje co do lokalizowania się w konkretnym miejscu w przestrzeni uzależnione są w dużym stopniu od decyzji poszczególnych podmiotów². Nie ulega jednak wątpliwości, że władze różnego szczebla mogą i powinny podejmować określone działania na rzecz realizacji przyjętych w polityce rozwoju przestrzennego celów, stymulując działanie sił dośrodkowych, służących w większym stopniu osiaganiu bardziej monocentrycznej struktury osadniczej, lub sił odśrodkowych, sprzyjających większemu rozpraszaniu ludności i uzyskiwaniu większego stopnia policentryczności tej struktury.

Celem niniejszego artykułu jest przede wszystkim analiza polskich uwarunkowań prawnych kształtowania sieci osadniczej w skali regionalnej i lokalnej w nawiązaniu do celów zrównoważonego rozwoju, który ma w Polsce status zasady konstytucyjnej. Chodzić będzie w szczególność o określenie tego, jaka sieć osadnicza - bardziej monocentryczna czy policentryczna - lepiej służyć będzie rozwojowi zrównoważonemu w skali lokalnej i regionalnej, a następnie ocena tego, czy w polskich regulacjach prawnych dostrzegany jest problem potrzeby właściwego kształtowania sieci osadniczej, sprzyjającej takiemu rozwojowi gmin, województw, a w efekcie całego kraju. Jest to zagadnienie istotne także ze względu na fakt, że na poziomie Unii Europejskiej zagadnieniom sieci osadniczej i powiązań między elementami tej sieci poświęca się dużo uwagi.

Artykuł ma charakter teoretyczno-analityczny, stąd też główną metoda badawczą w nim przyjęta jest analiza literatury i zgromadzonych dokumentów. Głównym źródłem informacji były przede wszystkim ustawa o planowaniu i zagospodarowaniu przestrzennym z 2003 r. (z późniejszymi zmianami) oraz Koncepcja Przestrzennego Zagospodarowania Kraju 2030, która - choć nie ma mocy wiążącej - to jednak jest podstawą do opracowywania dokumentów planistycznych na niższych szczeblach organizacji terytorialnej kraju.

\section{ZRÓWNOWAŻONY ROZWÓJ I JEGO CELE W SKALI REGIONALNEJ I LOKALNEJ}

W klasycznym ujęciu, zapisanym w Raporcie „Nasza wspólna przyszłość”, opracowanym i przyjętym przez Komisję ONZ pod przewodnictwem Gro Brundtland, zrównoważony rozwój rozumiany jest jako taki, który zaspokaja potrzeby współczesnego pokolenia bez narażania na szwank możliwości przyszłych pokoleń do zaspokajania ich własnych potrzeb ${ }^{3}$. Rozwój ten, zgodnie z zapisami raportu, opiera się na trzech podstawowych koncepcjach: potrzeb społecznych, które należy zaspokoić, ograniczeń, które stawiane sa gospodarce przez środowisko przyrodnicze, oraz sprawiedliwości wewnątrz- i międzypokoleniowej. Generalnie jednak jego istota jest koncepcja podtrzymywalności, rozumiana jako nieuszczuplanie kapitału naturalnego i gospodarowanie

\footnotetext{
2 J. Parysek, Wprowadzenie do gospodarki przestrzennej, WN UAM, Poznań 2006.

${ }^{3}$ G. H. Brundtland, Our Common Future, WCED, OUP, Oxford 1987.
} 
w ramach pojemności ekologicznej danego obszaru ${ }^{4}$. Tak pojmowany rozwój początkowo odnoszony był jedynie do skali globalnej, gdzie oznaczał gospodarowanie zasobami przyrodniczymi w taki sposób, aby nie pomniejszać ich wielkości ani nie naruszać równowagi ekosystemów. Z czasem zaś zyskał wymiar regionalny i lokalny.

Oprócz ogólnych sformułowań zawartych w raporcie Nasza Wspólna Przyszłość cele zrównoważonego rozwoju w skali regionalnej zapisane sa także w trzech prawach, opisanych przez Stefana Kozłowskiego ${ }^{5}$. Jednym z nich jest prawo regionu, z którego wynika, że każda tego typu jednostka powinna się rozwijać, opierając się na warunkach przyrodniczych i zgodnie z wola jego mieszkańców. Nie bez znaczenia jest przy tym utrzymanie lokalnych wartości i tradycji historyczno-kulturowych, a przez to odradzanie się tożsamości regionalnej ${ }^{6}$. Chodzi zatem w dużej mierze o kształtowanie samowystarczalności regionów, co musi być związane w określony sposób z jego strukturą osadniczą. Podejście takie zgodne jest co prawda z teorią regionalnego wzrostu endogenicznego, zgodnie z którym rozwój powinien być prowadzony przy wykorzystaniu wewnętrznych czynników rozwoju ${ }^{7}$, w pewnym stopniu także z teoria konwergencji, w której zakłada się zmniejszenie różnic, a nawet wyrównanie poziomu dochodów w różnego typu jednostkach ${ }^{8}$, jednak kłóci się to znacząco z licznymi teoriami rozwoju regionalnego (np. teorią rozwoju spolaryzowanego czy teorią biegunów wzrostu $\left.{ }^{9}\right)$.

Samowystarczalność jest także jednym z celów zrównoważonego rozwoju w skali lokalnej, gdzie jednak szczególna uwaga skupiona być powinna na kształtowaniu takich warunków życia i pracy, które umożliwiać będą każdemu mieszkańcowi włączenie się w procesy rozwojowe oraz spełnienie życiowych aspiracji. Zrównoważony rozwój w skali lokalnej polegać ma na odpowiednim i świadomym kształtowaniu relacji pomiędzy wzrostem gospodarczym, dbałością o środowisko (przede wszystkim przyrodnicze) oraz zaspokojeniem różnego typu potrzeb ludzkich, decydujących w znaczącym stopniu o jakości życia ${ }^{10}$. Szczegółowe cele rozwoju zrównoważonego w skali lokalnej w literaturze zwykle formułowane sa dla skali miasta lub téz miasta wraz z jego obszarem funkcjonalnym (aglomeracja miejska, obszar metropolitalny). W efekcie tego niektóre z miast starają się oszczędnie zarządzać przestrzenia, w innych równoważenie oznacza dążenie do zapewnienia wszystkim punktom

${ }^{4}$ L. Mierzejewska, Rozwój zrównoważony miasta: zagadnienia poznawcze i praktyczne, WN UAM, Poznań 2009.

5 S. Kozłowski, Ekorozwój: wyzwanie XXI wieku, WN PWN, Warszawa 2002.

${ }^{6}$ L. Mierzejewska, Przyrodnicze aspekty rozwoju zrównoważonego, Bogucki Wydawnictwo Naukowe, Poznań 2004.

7 P. Romer, Endogenous technological change, „Journal of Political Economy” 98, 1990, s. 71-102.

${ }^{8}$ P. Churski, Czynniki rozwoju regionalnego i polityka regionalna $w$ Polsce $w$ okresie integracji europejskiej, WN UAM, Poznań 2008.

9 Ibidem.

${ }^{10}$ A. I. Petrișor, L. E. Petrișor, The shifting relationship between urban and spatial planning and the protection of the environment: Romania as a case study, „Present Environment and Sustainable Development” 7(1), 2013, s. 268-276. 
sieci osadniczej takich samych możliwości rozwoju ${ }^{11}$. W aspekcie przestrzennym zwraca się przede wszystkim uwagę na odpowiednie proporcje między poszczególnymi elementami struktury użytkowania ziemi, wzajemne niekonfliktowe rozmieszczenie różnych form użytkowania ziemi, zwiększenie wielofunkcyjności osiedli oraz w miarę wyrównany dostęp wszystkich mieszkańców do różnego rodzaju usług (głównie do usług podstawowych i terenów rekreacyjno-wypoczynkowych) ${ }^{12}$. Specyfika skali miasta, zwłaszcza dużego, polega jednak na tym, że jednostka ta ze swej natury nie jest samowystarczalna. Nie jest także możliwe prowadzenie w granicach miasta rozwoju podtrzymywalnego, czyli gospodarowania w ramach jego pojemności ekologicznej.

Realizacja sformułowanych w Raporcie Nasza Wspólna Przyszłość założeń zrównoważonego rozwoju na danym obszarze wymaga uwzględnienia praktycznie wszystkich wymiarów rozwoju, w tym także przestrzennego. Stąd też zrównoważony rozwój pojmować można jako swego rodzaju megaład, integrujący ład społeczny, gospodarczy, ekologiczny, a także ład instytucjonalny i przestrzenny ${ }^{13}$. Wyznaczona zgodnie z ideą rozwoju zrównoważonego trajektoria rozwoju przestrzennego powinna być przy tym akceptowalna społecznie, wykonalna politycznie i technicznie oraz uzasadniona ekonomicznie ${ }^{14}$.

\section{REGIONALNA I LOKALNA SIEĆ OSADNICZA W ŚWIETLE IDEI ZRÓWNOWAŻONEGO ROZWOJU}

Przestrzenny wymiar zrównoważonego rozwoju podkreślany jest bezpośrednio w raporcie Brundtland, w którym zwraca się uwagę na „skoncentrowany-zdecentralizowany" model osadnictwa jako najbardziej korzystny z punktu widzenia redukcji presji wywieranych na środowisko przyrodnicze przez rozrastające się aglomeracje miejskie ${ }^{15}$. W modelu tym proponuje się tworzenie gęstszej sieci mniejszych miast, zintegrowanych w bardziej efektywny sposób między sobą oraz z sąsiadującymi z nimi terenami rolniczy$\mathrm{mi}^{16}$. Odpowiednie użytkowanie ziemi postrzegane jest jako remedium na powstrzymanie niekorzystnych zmian zachodzących w ekosystemach, $\mathrm{w}$ tym

\footnotetext{
${ }^{11}$ P. Fogel, Wskaźniki zrównoważonego rozwoju przestrzennego miasta, 2014, file:///E:/e_czasopisma/policentryzm/Fogel_artykul.pdf [dostęp: 8.07.2017].

${ }^{12}$ L. Mierzejewska, Miasto zwarte, rozproszone, zrównoważone, „Studia Miejskie” 19, 2015, s. $9-22$.

${ }^{13}$ T. Markowski, Warunki osiagania megaładu przestrzennego a system planowania przestrzennego, „Biuletyn KPZK PAN” 2003, z. 205, s. 9-24; L. Mierzejewska, Przyrodnicze aspekty..., passim.

${ }^{14}$ D. Shipworth, Environmental impact mitigation is not sustainable development, „Building Research and Integration” 30, 2002, s. 139-142; M. Olazabal et al., OIKOS: an integrated Approach towards sustainable spatial planning and management, w: M. Horner et al. (eds.), International Conference on Whole Life Urban Sustainability and Its Assessment, Glasgow 2007.

${ }^{15}$ G. H. Brundtland, op. cit.

${ }^{16}$ P. M. Delladetsima, Sustainable development and spatial planning: some considerations arising from the Greek case, „European Journal of Spatial Development” 46, 2012.
} 
w zakresie przepływu energii, a tym samym jako droga do osiagnięcia zrównoważonego rozwoju ${ }^{17}$.

$\mathrm{Na}$ policentryczną strukturę przestrzenną w skali lokalnej, jako zgodna z zasadami zrównoważonego rozwoju, zwraca uwagę Graham Haughton ${ }^{18}$ w przywoływanym już wyżej modelu miasta samowystarczalnego. W modelu tym w odniesieniu do osadnictwa mowa jest o ograniczaniu liczby dużych miast i zwiększaniu liczby miast małych i średnich, ograniczaniu rozmiarów miasta, potrzebie integrowania zabudowy $\mathrm{z}$ elementami przyrodniczymi, większym zróżnicowaniu form użytkowania ziemi w miastach, a zwłaszcza na terenach podmiejskich oraz o przywracaniu w miastach wolnej przestrzeni i elementów przyrodniczych ${ }^{19}$.

Przestrzenne aspekty zrównoważonego rozwoju zajmują także ważne miejsce w zasadach przyjmowanych w ramach polityki Unii Europejskiej. Mowa w niej o „spójności terytorialnej”, wymagającej uwzględnienia zrównoważonej dystrybucji aktywności ludzkiej na danym obszarze oraz poprawy warunków życia w mieście m.in. przez realizację efektywnych procesów rewitalizacyjnych, a także policentryczność, przez którą rozumie się organizację regionu wokół kilku centrów politycznych, społecznych i finansowych ${ }^{20}$.

W podpisanym w 2005 r. przez Ministrów UE ds. Rozwoju Miast Porozumieniu z Bristolu zapisano z kolei, że punktem wyjścia zrównoważonego rozwoju przestrzennego w różnych skalach przestrzennych jest tworzenie „zrównoważonych wspólnot”, definiowanych jako „miejsca, w których ludzie chcą żyć i pracować, teraz i w przyszłości” ${ }^{21}$. Podkreśla się przy tym korzyści wynikajace z policentrycznej struktury przestrzennej, sama zaś policentryczność rozumiana jest jako organizacja przestrzenna charakteryzująca się „funkcjonalnym podziałem pracy, integracja gospodarczą i instytucjonalna oraz współpracą polityczną"22.

\section{SIEĆ OSADNICZA \\ W AKTACH PLANOWANIA PRZESTRZENNEGO W POLSCE}

Podstawowym aktem prawnym regulujacym planowanie przestrzenne w Polsce jest ustawa o planowaniu i zagospodarowaniu przestrzennym z 2003 r., z późniejszymi zmianami, w której za podstawowe zasady przyjęto

17 V. H. Dale, R. A. Efroymson, K. I. Kline, op. cit.; A. I. Petrișor, C. N. Sârbu, Dynamics of geodiversity and eco-diversity in territorial system, „Journal of Urban and Regional Analysis” 2(1), 2010, s. 61-70; A. I. Petrișor, L. E. Petrișor, op. cit.

18 G. Haughton, Developing sustainable urban development models, „Cities” 14(4), 1997, s. $189-95$.

19 L. Mierzejewska, Przyrodnicze aspekty..., passim.

${ }^{20}$ A. I. Petrișor, L. E. Petrișor, op. cit.

${ }^{21}$ Office of the Deputy Prime Minister - ODPM, A common approach to creating sustainable communities: „The Bristol Accord”, Document 05 EUPMI 03656/A, w: UK Presidency. EU Ministerial Informal on Sustainable Communities. Policy Papers, ODPM Publications, London 2006, UK.

${ }^{22}$ Nordic Centre for Spatial Development, ESPON 1.1.1. Potentials for polycentric development. Final Report, NORDREGIO, Sweden 2005. 
ład przestrzenny i zrównoważony rozwój. Z zapisów tej ustawy wynika de facto trójszczeblowy podział kompetencji w przedmiotowym zakresie. Na najwyższym szczeblu - krajowym - opracowywana jest Koncepcja Przestrzennego Zagospodarowania Kraju - 2030, która jednak nie ma waloru aktu prawnego wewnętrznie obowiazujacego, a tym bardziej aktu wiążącego powszechnie. $\mathrm{Na}$ szczeblu województwa, które w Polsce potraktować można jako region, opracowywany jest plan zagospodarowania przestrzennego, który pod względem prawnym jest aktem kierownictwa wewnętrznego. Na lokalnym szczeblu gminy natomiast powstają dwa dokumenty o różnym charakterze prawnym. Pierwszy to studium uwarunkowań i kierunków zagospodarowania przestrzennego gminy (nazywane studium) - akt kierownictwa wewnętrznego, drugi zaś - miejscowe plany zagospodarowania przestrzennego (tzw. plany miejscowe), będące aktami prawa miejscowego. Zakres dokumentów opracowywanych dla skali lokalnej jest taki sam bez względu na to, czy mamy do czynienia z mała gminą wiejska, czy z dużym miastem ${ }^{23}$. Jeśli jednak na danym obszarze powołany został związek metropolitalny, jest on zobowiązany do opracowania studium uwarunkowań i kierunków zagospodarowania przestrzennego związku metropolitalnego (zwane studium metropolitalnym), będącego aktem kierownictwa wewnętrznego, uwzględniającego ustalenia planu zagospodarowania przestrzennego województwa.

W zapisach ustawy odnoszących się do studium uwarunkowań i kierunków zagospodarowania gminy trudno jest odnaleźć jakiekolwiek sformułowania dotyczące kształtowania zgodnej z zasadami zrównoważonego rozwoju struktury osadniczej, zarówno w części dotyczącej uwarunkowań, jak i wyznaczania kierunków zagospodarowania przestrzennego gminy. Odniesień takich brak również w regulacjach dotyczacych opracowywania planów miejscowych oraz studium metropolitalnego.

Zgodnie $\mathrm{z}$ zapisami ustawy $\mathrm{w}$ planie zagospodarowania przestrzennego województwa uwzględnia się podstawowe elementy jego sieci osadniczej i ich powiązania komunikacyjne oraz infrastrukturalne, w tym kierunki powiązań transgranicznych. Podstawowe elementy krajowej sieci osadniczej sa też wymaganym elementem Koncepcji Przestrzennego Zagospodarowania Kraju, która określa uwarunkowania, cele i kierunki zrównoważonego rozwoju kraju. W obu dokumentach brak jednak jakichkolwiek wskazań co do tego, jaka sieć osadnicza byłaby najbardziej pożądana i jak należałoby ją kształtować. Warto przy tej okazji jeszcze raz podkreślić, że koncepcja taka nie ma żadnej mocy wiążącej.

Istotne z punktu widzenia zrównoważonego rozwoju jest także uspołecznienie procesów planowania przestrzennego. W polskich uwarunkowaniach prawnych partycypacja społeczna przewidziana jest tylko w skali lokalnej, i to w szczątkowej formie. W skali regionu i kraju ustawodawca nie przewidział takiej możliwości.

Głównym dokumentem, zgodnie z którym prowadzona jest obecnie polityka przestrzenna kraju, jest Koncepcja Przestrzennego Zagospodarowania Kraju 2030. W koncepcji tej sieć osadnicza zaliczona została do podstawo-

${ }^{23}$ J. Parysek, Rola lokalnego samorzqdu terytorialnego w rozwoju społeczno-gospodarczym i przestrzennym gmin, „Ruch Prawniczy, Ekonomiczny i Socjologiczny” 77(2), 2015, s. 27-46. 
wych elementów struktury przestrzennej kraju, będących przedmiotem analiz i oddziaływania polityki publicznej. Zapisano w nim, że Polska ma jeden z najbardziej policentrycznych systemów osadniczych w Europie, co uznane zostało za bardzo korzystną cechę polskiej przestrzeni. Zwrócono uwagę na to, że „metropolie i miasta o znaczeniu regionalnym biorą udział w globalnej konkurencji o inwestycje oraz uczestniczą w przepływach kapitału, towarów, usług, ludzi i technologii”. Uznano, że taka historycznie ukształtowana, zrównoważona przestrzennie sieć dużych ośrodków miejskich zwiększa konkurencyjność Polski na arenie międzynarodowej, a także odgrywa ważną rolę w budowaniu spójności społeczno-gospodarczej i terytorialnej kraju, przyspieszając rozprzestrzenianie się procesów rozwojowych. Stwierdzono, że Polska struktura osadnicza nie uległa w ostatnich dekadach dużym zmianom. W dalszym ciągu obserwuje się urbanizację oraz suburbanizację, polegająca na koncentracji ludności w stale powiększających się obszarach otaczających największe polskie miasta.

Z wymienionych wyżej powodów w Koncepcji Przestrzennego Zagospodarowania Kraju przyjęto, że rozwój przestrzenny kraju odbywać się powinien zgodnie z modelem polaryzacyjno-dyfuzyjnej polityki rozwoju regionalnego ${ }^{24}$. Polityka taka opiera się na założeniu, że należy wspierać silne centra rozwoju (tzw. lokomotywy rozwoju), a obszary je otaczajace będą korzystały z dyfuzji (tzw. spill-over) efektów ekonomicznych i społecznych. Model ten nawiąuje do teorii neoklasycznej, która podkreśla, że wspieranie obszarów peryferyjnych jest nieefektywne, a aktywizowanie obszarów o niskim poziomie rozwoju jest marnotrawstwem ograniczonych środków publicznych. Transfery finansowe dla tego typu obszarów powinny jedynie zapewniać dostęp do podstawowych usług publicznych ${ }^{25}$. Policentryczna metropolia sieciowa, ukształtowana na bazie dużych ośrodków miejskich, ma być rdzeniem krajowego systemu gospodarczego i ważnym elementem systemu europejskiego. Dyfuzja wypracowanych przez nie korzyści ma nastapić automatycznie na późniejszych etapach rozwoju.

\section{POSZUKIWANIE WŁAŚCIWYCH ROZWIĄZAŃ}

Jednym z najczęściej wymienianych celów polityki przestrzennej Unii Europejskiej jest promowanie policentryczności, czyli „zrównoważonego, policentrycznego systemu miejskiego". Zasadniczo dyskutowane są w tym względzie dwa warianty ${ }^{26}$ :

${ }^{24}$ J. Rakowska, Praktyczne znaczenie zastosowania wyrównawczego lub polaryzacyjno-dyfuzyjnego modelu rozwoju regionalnego dla obszarów wiejskich w Polsce po 2013 roku, „Wieś Jutra. Nauka Doradztwo Praktyka" 11/12(160/161), 2011, s. 26-27.

${ }_{25}$ J. Szlachta, Strategiczne programowanie rozwoju regionalnego, $w$ kierunku krajowego systemu myśli strategicznej $w$ sferze polityki regionalnej, w: Nowy paradygmat rozwoju-najnowsze trendy i perspektywy rozwoju polityki regionalnej, Ministerstwo Rozwoju Regionalnego, Warszawa 2011; J. Rakowska, op. cit.

${ }^{26}$ M. Wegener, Polycentric Europe: more efficient, more equitable and more sustainable? Paper presented at the seminar Welfare and Competitiveness in the European Polycentric Urban 
- wzmocnienie kilku większych stref globalnej integracji gospodarczej w UE, wyposażonych w wysokiej jakości, globalne funkcje i usługi, w tym obszary peryferyjne, przez międzynarodowe strategie rozwoju przestrzennego;

- wzmocnienie policentrycznego i bardziej zrównoważonego systemu regionów metropolitalnych, klastrów miast i sieci miast przez ściślejszą współpracę między polityką strukturalną a innymi politykami sektorowymi, takimi jak polityka transportowa i innowacyjna.

Przyjęty w Polsce model polaryzacyjno-dyfuzyjnego rozwoju regionalnego zdaje się wpisywać w pierwszy z wymienionych wariantów.

Zainteresowanie rozwojem policentrycznym w Unii Europejskiej opiera się na hipotezie, że policentryczne systemy miejskie są bardziej wydajne, bardziej zrównoważone i sprawiedliwe niż monocentryczne systemy miejskie i rozproszone małe osady ${ }^{27}$. Pojęcie policentryczności struktur osadniczych powstało w latach trzydziestych XX w. Wtedy to została opracowana przez Waltera Christallera teoria ośrodków centralnych, wyjaśniająca hierarchiczną decentralizację miast, ustaloną na podstawie różnych obszarów obsługi mieszkańców w zakresie dostępu do towarów i usług ${ }^{28}$ oraz obszarów targowych ${ }^{29}$ różnej wielkości Augusta Löscha. Później w koncepcji rozwoju spolaryzowanego zaprezentowano alternatywny, dość kontrowersyjny wówczas pogląd, że rosnące ekonomie skali prowadzą do wzrastającej koncentracji tylko w kilku dużych miastach, przyczyniając się do wzrostu ich konkurencyjności ${ }^{30}$. Cechą wspólną obu perspektyw jest to, że są związane z efektami ekonomicznymi osiaganymi $\mathrm{w}$ skali regionu ${ }^{31}$. Kwestie policentryczności były przedmiotem zainteresowania przedstawicieli różnych dziedzin nauki, a podstawowym dylematem w doborze konkretnej polityki rozwoju przestrzennego stało się to, czy wspierać konkurencyjność czy spójność terytorialną danej jednostki.

Mimo pewnej niejednoznaczności, po II wojnie światowej wiele krajów w wyznaczaniu kierunków ich rozwoju przestrzennego przyjęło teorię ośrodków centralnych Christallera. Przyjmowano, że systemy ośrodków centralnych są zarówno efektywne (w kategoriach ekonomii skali), jak i sprawiedliwe społecznie (w kategoriach równoważnych warunków życia). Można jednak stwierdzić, że zarówno skrajne, monocentryczne (wszystkie działania są skoncentrowane w jednym ośrodku), jak i dyspersyjne (wszystkie działania są rów-

Structure: Which Role for Metropolitan, Medium and Small Cities? at the Istituto Regionale Programmazione Economica della Toscana (IRPET), Florence, 7 June 2013.

${ }^{27}$ Ibidem.

${ }^{28}$ W. Christaller, Die zentralen Orte in Süddeutschland. Eine ökonomisch-geographische Untersuchung über die Gesetzmässigkeit der Verbreitung und Entwicklung der Siedlungen mit städtischen Funktionen, 66, Jena 1933.

${ }_{29}$ A. Lösch, Die räumliche Ordnung der Wirtschaft, Jena 1940; New edition: Fischer, Stuttgart 1962.

${ }^{30}$ F. Perroux, Note sur la notion du pôle de croissance, „Économie Appliquée” 1955, s. 307-320; G. Myrdal, Economic Theory and Underdeveloped Regions, Duckworth, London 1957; G. Myrdal, Economic Theory and Underdeveloped Regions, Duckworth, London 1957.

${ }^{31}$ P. Krugman, Geography and Trade, Leuven University Press, Leuven 1991; M. Fujita, P. Krugman, A. J. Venables, The Spatial Economy: Cities, Regions and International Trade, MIT Press, Cambridge, MA, 1999. 
nomiernie rozproszone w przestrzeni) systemy osadnicze mają swoje wady i zalety w kontekście skuteczności realizacji celów politycznych, sprawiedliwości i trwałości, co szczegółowo opisał Michael Wegener ${ }^{32}$. Wynika stąd, że optymalizacja leży gdzieś pomiędzy monocentrycznością i rozproszeniem, tj. w zrównoważonej mieszance dużych, średnich i małych miast, rozmieszczonych w układzie korzystnym z punktu widzenia możliwości prowadzenia wymiany i współpracy ${ }^{33}$.

Zagadnienie policentryczności i sposoby jej pomiaru opracowane na podstawie zrealizowanych projektów ESPON, a także scenariusze co do przyszłych kierunków zmian w tym zakresie w Unii Europejskiej opisane zostały m.in. przez Wegenera ${ }^{34}$. Z prowadzonych w jednym z tych projektów badań wynika, że na tle państw UE sieć osadniczą w Polsce faktycznie uznać można za policentryczna, co zdiagnozowano w Koncepcji Przestrzennego Zagospodarowania Kraju 2030, a o czym świadczy wyliczony przez autorów projektu wysoki wskaźnik policentryczności. Ten sam wskaźnik obliczony dla jednostek NUTS 1 dał jednak inny obraz i pozwolił zaliczyć Polskę do grupy regionów o średnim poziomie policentryczności ${ }^{35}$.

Prawdopodobnie z tego między innymi powodu przyjęty w Polsce polaryzacyjno-dyfuzyjny model polityki rozwoju nie wydaje się szczególnie obiecujacy. Zwraca się uwagę na to, że zarówno procesy globalizacji, jak i realizacja tego modelu generują impulsy pogłębiające nierówności rozwojowe, co uzasadnia sceptyczny punkt widzenia. Ponadto liczba miast - potencjalnych lokomotyw rozwoju - jest niewystarczająca, a ich rozmieszczenie na mapie Polski nierównomierne, co w przypadku zastosowania takiego modelu rozwoju pozostawi znaczną część obszarów kraju poza zasięgiem oddziaływania instrumentów polityki spójności przeznaczonych dla miast ${ }^{36}$. Kreśli to pesymistyczne perspektywy osiagania spójności społeczno-ekonomicznej. Dotyczy to w szczególności sytuacji i poziomu rozwoju wschodnich województw, co przekłada się na zagrożenia dla osiągania spójności w skali kraju. W strukturze osadniczej wschodnich województw brakuje bowiem metropolii. Ponadto województwa wschodnie nie sa jeszcze gotowe, by budować swoją przewagę konkurencyjna, opierając się na kapitale intelektualnym ${ }^{37}$. Model polaryzacyjno-dyfuzyjny nie służy także budowaniu gospodarek samowystarczalnych ani nie zakłada uspołecznienia procesów planistycznych. W niewielkim stopniu nawiąuje zatem do zrównoważonego rozwoju.

Rozstrzygnięcie strategicznego dylematu polityki rozwoju w zakresie wyboru między konkurencyjnością a spójnością terytorialną wymaga poszukiwania alternatywnej koncepcji rozwoju ${ }^{38}$. Koncepcję taką rekomendują Barbara Pion-

${ }^{32}$ M. Wegener, op. cit.

${ }^{33}$ Ibidem.

${ }^{34}$ Ibidem.

${ }^{35}$ Ibidem.

${ }^{36}$ J. Rakowska, op. cit.

${ }^{37}$ M. Wosiek, Uwarunkowania rozwoju regionów peryferyjnych $w$ Polsce $w$ czasach kryzysu finansów publicznych - wnioski dla spójności społeczno-ekonomicznej, „Nierówności Społeczne a Wzrost Gospodarczy" 2013, z. 31, s. 318-333.

${ }^{38}$ Ibidem. 
tek i Franciszek Piontek ${ }^{39}$, proponując zamiast modelu polaryzacyjnego koncepcję urzeczywistniania rozwoju w wymiarze lokalnym według modelu niszy. Model ten jest silnie zakorzeniony w zasadach zrównoważonego rozwoju i respektuje leżące u jego podstaw aksjomaty i prawo naturalne ${ }^{40}$. W dokumentach opracowywanych przez OECD z kolei w ogóle nie wskazuje się na konkretny model rozwoju sieci osadniczej. Przyjmuje się, że nie ma uniwersalnego modelu odpowiadającego potrzebom rozwojowym wszystkich regionów, ponieważ rozwijają się one, ulegają stagnacji lub degradacji w różny sposób i z różnym nasileniem. Proponowana jest natomiast koncepcja doboru modelu do typu regionu, jego bieżącej sytuacji i perspektyw rozwojowych. Dało to podstawy do ukształtowania podejścia „policentrycznej sieci”, gdzie obszary miejskie i wiejskie sa postrzegane jako komplementarne, a nie konkurencyjne względem siebie ${ }^{41}$.

\section{PODSUMOWANIE}

Zasada zrównoważonego rozwoju jest najczęściej przywoływanym pryncypium $\mathrm{w}$ kształtowaniu przestrzeni na różnych szczeblach organizacji terytorialnej kraju. Konieczność jej respektowania wynika zarówno z powszechnie obowiązujących przepisów prawa, jak i dostrzeganej potrzeby ochrony zasobu, jakim jest przestrzeń ${ }^{42}$.

Trudno jednoznacznie ocenić, czy polskie regulacje prawne w zakresie kształtowania regionalnej i lokalnej sieci osadniczej służą realizacji zasad zrównoważonego rozwoju. Generalnie nie ma w nich odniesień do sposobu kształtowania takiej zrównoważonej sieci. Sformułowany natomiast w Koncepcji Przestrzennego Zagospodarowania Kraju 2030 model polaryzacyjno-dyfuzyjny trudno jednoznacznie uznać za zgodny z celami zrównoważonego rozwoju. Sprzyja bowiem powiększaniu nierówności społeczno-gospodarczych, nie zaś zwiększaniu spójności, dbałości o zaspokojenie potrzeb społecznych czy zapewnianiu sprawiedliwości wewnątrzpokoleniowej. Trudno więc ocenić, jakie efekty przyniesie realizacja w praktyce takiego modelu rozwoju dla dość dobrze ukształtowanej, policentrycznej struktury przestrzennej Polski.

Istnieje co prawda porozumienie co do tego, że promowanie największych obszarów metropolitalnych kosztem drugorzędnych miast przynieść może maksymalny wzrost ze względu na ich globalną spójność, efekty aglomeracji i najwyższa wydajność, ale przy świadomości tego, że taka polityka zwiększyć może nierówności gospodarcze między regionami. Zgoda jest również co do tego, że priorytetowe wsparcie regionów wiejskich i peryferyjnych w ich rozwoju, zwłaszcza regionów w nowych państwach członkowskich, zmniejszyłoby dysproporcje gospodarcze w Europie, ale spowodowałoby niższy wzrost gospodarczy. Połącze-

${ }^{39}$ F. Piontek, B. Piontek, Zarzqdzanie rozwojem niszowym dla zapewnienia spójności społeczno-ekonomicznej, „Nierówności Społeczne a Wzrost Gospodarczy” 2012, z. 24.

40 M. Wosiek, op. cit.

${ }^{41}$ J. Bachtler (ed.), Where is Regional Policy Going? Changing Concepts of Regional Policy. European Policies Research Centre, University of Strathclyde 2001, www.eprc.strath.ac.uk/eorpa-/Documents/EoRPA_01_Papers/EoRPA_01-5.pdf [dostęp: 25.03.2011]; J. Rakowska, op. cit.

${ }^{42}$ P. Fogel, op. cit. 
nie tych dwóch ujęć wydaje się raczej niemożliwe ${ }^{43}$. Przyjąć jednak można, że w określonych uwarunkowaniach przez ograniczony czas może być potrzebne kontynuowanie wsparcia stolic nowych państwach członkowskich Unii Europejskiej, w tym Polski, aby jak najszybciej pomogły im rozwijać gospodarkę całego kraju, ale że w dłuższej perspektywie kraje te powinny prowadzić działania na rzecz rozwijania miast małych i średnich w kierunku zrównoważonego, policentrycznego systemu miejskiego ${ }^{44}$. Działania takie powinny być podejmowane przede wszystkim na szczeblu regionalnym i lokalnym, tzn. wzmacniać te miasta, które ze względu na bliskość terytorialną mogą stanowić potencjał gęstszej sieci miejskiej i przynieść efekty spin-off ${ }^{45}$.

Rozstrzygnięcie strategicznego dylematu polityki rozwoju w zakresie alternatywnego wyboru między konkurencyjnością a spójnością terytorialna wydaje się w najbliższych latach nieosiagalne. Coraz liczniejsze są jednak głosy ekonomistów postulujaccych eklektyczne, holistyczne czy zintegrowane (ukierunkowane na wszystkie sfery bytu ludzkiego) podejście do procesów rozwojowych, w ramach którego możliwe jest łączenie wymogów konkurencji z większą wrażliwością na kwestie nierówności społeczno-ekonomicznych ${ }^{46}$. Taki układ odniesienia daje szansę na zbudowanie innych, w stosunku do obecnych, mechanizmów alokacji, dzięki którym możliwe byłoby maksymalizowanie dobrobytu (jako konsekwencji spójności społeczno-ekonomicznej) bez ujemnych następstw dla konkurencyjności i efektywności ekonomicznej ${ }^{47}$.

Racjonalnym kompromisem między sprzecznymi celami wzrostu i równości może być strategia policentryczności, polegająca na promowaniu wielopoziomowego systemu miast o różnej wielkości, funkcjach usługowych i interakcjach $^{48}$. Policentryczność nie może być jednak celem samym w sobie, ale sposobem na osiagnięcie bardziej zrównoważonej i bardziej sprawiedliwej struktury przestrzennej. Korzyści wynikające z policentryczności z punktu widzenia dobrobytu gospodarczego, równości społecznej i przestrzennej oraz trwałości środowiska nie są obietnicą bez pokrycia, ale poparte są licznymi badaniami naukowymi.

dr hab. Lidia Mierzejewska

Profesor Uniwersytetu im. Adama Mickiewicza w Poznaniu mierzeja@amu.edu.pl

${ }^{43}$ M. Wegener, op. cit.

44 Ibidem.

${ }^{45}$ Strategy for a Regional Polycentric Urban System in Central Eastern Europe Economic Integrating Zone RePUS. NTERREG III B, http://www.espon-interstrat.eu/admin/attachments/ ZL_dsresource.pdf [dostęp: 8.07.2017].

${ }^{46}$ M. G. Woźniak, Teoretyczne i praktyczne kwestie budowy spójności społeczno-ekonomicznej dla gospodarki innowacyjnej, w: M. G. Woźniak (red.), Gospodarka Polski 1990-2011. Transformacja. Modernizacja. Spójność społeczno-ekonomiczna, t. 3: Droga do spójności społeczno-ekonomicznej, WN PWN, Warszawa 2012; B. Fiedor, Kryzys gospodarczy a kryzys ekonomii jako nauki, „Ekonomista” 2010, nr 4; G. W. Kołodko, Nowa gospodarka-szanse i wyzwania, w: M. Piątkowski (red.), Nowa gospodarka a transformacja, Wyd. WSPiZ im. L. Koźmińskiego w Warszawie, Warszawa 2003; M. Horx, Die acht Sphären der Zukunft, Signum, Wien-München 2002; F. Piontek, B. Piontek, op. cit.

47 M. G. Woźniak, op. cit.

${ }^{48}$ M. Wegener, op. cit. 


\section{EVOLUTION OF THE REGIONAL AND LOCAL SETTLEMENT NETWORK IN POLAND IN THE LIGHT OF THE IDEA OF SUSTAINABLE DEVELOPMENT}

\section{Sum mary}

Sustainable development in Poland is a constitutional principle and therefore should underlie all actions. For this reason it should be expected that this principle be present in legal regulations concerning development policies at various levels of the territorial organisation, including the spatial policy. The possibility of the implementation of sustainable development in different spatial scales is determined, among other things, by the manner in which population is distributed in a given area. The aim of the article is to define which settlement network, regionally and locally scale, will support the implementation of sustainable development. Next, the paper also aims to analyse whether there are references in Polish legal regulations to the development of a network that will be compatible with sustainable development. The analysis shows that it is predominantly a polycentric settlement structure that will help to achieve the objectives of such development, both on the regional and local scale. The Act on Planning and Spatial Development currently in force in Poland makes no references to the policy or regulations governing development of settlement networks, which may be one of the reasons for numerous inefficient, unsustainable spatial structures that can frequently be observed, as well as for the fact that the polarisation-diffusion model of development adopted in the Concept of the Spatial Development of the Country 2030 does not fully serve to achieve the objectives of sustainable development. 